Theories \& Applications, the International Edition

Printed Version : (ISSN 2090-5262)

Online Version : (ISSN 2090-5270)

November 2014, Volume 4, No. 3 Pages $(97$ - 101)

\title{
S-100ß Protein in Relation to Skills Evaluation Test for Brain Damage in Pole Vault and High Jump Players after Competition.
}

\section{Dr. Badiea Ali Abdel Samie}

Assistant Professor of training in track and field events, Faculty of physical education for girls, Helwan Univesrity, Egypt.

\begin{abstract}
Background: Sport-related mild head injuries/concussions are common in pole vault and high jump players but there is no study that was designed specifically to investigate the biochemical markers of brain damage .

$S-100 \beta$ serum levels may elucidate whether these games causes minor brain damage by increasing serum concentration and to shed some light on its possible use for assessment of concussed athletes. The aim of the present study was to investigate $S$ $100 \beta$ in the blood of elite pole vault versus high jump players before and after a competitive game and to relate the changes in concentration to head trauma

Material and Methods: Ten male elite pole vaults versus another ten high jump players participated in the national field and track games for youth under 20 years held in the Olympic centre $(13$ - 15 /4/2011) constituted subjects of this study, their serum protein was assayed before and after the game events. Skills evaluation test was performed before and after the competition.

Results: Changes in serum concentrations of $S-100 \beta$ (post-game - pre-game values) were statistically significant after both games. In pole vault, there was a significant correlation between the changes in $S$-100ß (post-game-pre-game values). For pole vault players, $S-100 \beta$ was increased more than for the high jump players.

Conclusions: $S-100 \beta$ was released into the blood of the players as a consequence of game-related activities and events. $S$ $100 \beta$ analysis as a biochemical marker for brain damage seems to have the potential to become a valuable additional tool for assessment of the degree of brain tissue damage in sport-related head trauma and probably for decision making about inhibiting/returning to play.
\end{abstract}

\section{Introduction}

$\mathrm{R}$ unning, jumping and throwing competitions are called track and field or athletics. They are probably the oldest form of sport and an important part of the Olympic Games. The jumping events at athletic meets are the high jump, the pole vault, the long jump and the triple jump. In the high jump, athletes have to jump over a metal stick called a crossbar, without knocking it down. It is placed on two vertical poles. Most modern jumpers pass over the crossbar with their heads first. Pole vaulters must jump over a much higher crossbar. They have long flexible poles that may be up to five meters long. They run towards the crossbar and before they get there, they plant the pole into a small box on the ground. Then they thrust themselves high up into the air and try to get over the bar (Watson et al., 2005).

Pole vaulting is a track and field event in which a person uses a long, flexible pole (which today is usually made either of fiberglass or carbon fiber) as an aid to jump over a bar. Pole jumping competitions were known to the ancient Greeks, Cretans and Celts. It has been a full medal event at the Olympic Games since 1896 for men and 2000 for women. It is typically classified as one of the four major jumping events in athletics, alongside the high jump, long jump and triple jump. It is unusual among track and field sports in that it requires a significant amount of specialized equipment in order to participate, even at a basic level.

Sport-related mild head injuries/concussions are common in pole vault and high jump players but there is no study that was designed specifically to investigate the biochemical markers of such brain damage. Recent studies have provided evidence that exercise triggered hyperthermia profoundly influences brain function during exercise, resulting in altered brain activity (Nielsen et al., 2001), reduced voluntary activation of muscle during sustained contractions (Nybo and Nielsen, 2001-A), and increased perception of effort (Nybo and Nielsen, 2001-B). Fatigue may be mediated through mechanisms residing within the central nervous system (CNS) which is known as central fatigue, but at present the neurobiological mechanisms that may be involved are not apparent.

Concussion is the historical term representing low velocity injuries that cause brain 'shaking' resulting in clinical symptoms and that are not necessarily related to a pathological injury. Concussion is a brain injury and is defined as a complex pathophysiological process affecting the brain, induced by biomechanical forces. Several common features that incorporate clinical, pathologic and biomechanical injury constructs that may be utilized in defining the nature of a concussive head injury include concussion that may cause either direct blow to the head, 
face, neck or elsewhere on the body with an 'impulsive' force transmitted to the head. Also, concussion typically results in the rapid onset of short-lived impairment of neurological function that resolves spontaneously. However, in some cases, symptoms and signs may evolve over a number of minutes to hours. Concussion may result in neuropathological changes, but the acute clinical symptoms largely reflect a functional disturbance rather than a structural injury and, as such, no abnormality is seen on standard structural neuroimaging studies. It results in a graded set of clinical symptoms that may or may not involve loss of consciousness. Resolution of the clinical and cognitive symptoms typically follows a sequential course. However, it is important to note that in some cases symptoms may be prolonged (McCorory et al., 2009).

$\mathrm{S}-100 \beta$ is a calcium-binding peptide produced by reactive brain astrocytes and observed mainly in the cytoplasm of astrocytes (Maramatsu et al. 2003) and Schwann cells (Isobe et al. 1984). It is known that $S-100 \beta$ plays a role in neuronal plasticity and long-term potentiation processes (Kiełbińska and Sołtys 2008). This protein is expressed at high levels in the brain and is known to be a marker of brain damage. The presence of this protein in blood serum indicates functional and/or morphological disruption of the blood-brain barrier (BBB). This protein is generally considered to be a marker of CNS damage (Kapural et al. 2002, Sendrowski et al. 2004).

Several investigations have detected elevations in serum S$100 \beta$ following participation in various sports that involve mechanical impact, such as boxing, submaximal endurance like marathon running or swimming, and short but high intensity activities like sprinting (Otto et al., 2000; Hasselblatt et al., 2004; Dietrich et al., 2003). Pole vault and high jump games usually cause recurrent head crash and hence lead to minor head or brain damage with increased levels of S-100 $\beta$ protein in plasma. As far as the investigator knowledge, there are no any previous studies concerned such brain damage with the followed concussion on those players.
The aim of this study was to assess the effect of pole vault and high jump events after an official competitive game (National field and track games for youth under 20 years held in the Olympic centre $(13-15$ /4/2011). Serum S-100 $\beta$ protein was measured before (at rest) and after the competition of these games. The results were compared and evaluated for minor brain damage or not with or without concussion by skills evaluation sheet assayed before and after the competition.

\section{Material and Methods}

\section{Subjects:}

Prior to their participation, 20 male non-smoker (age: $19.3 \pm 1.6$ years, body mass: $74.2 \pm 5.9 \mathrm{~kg}$, body height: $181.0 \pm 3.7 \mathrm{~cm}$, (mean+SD) received written information about this study which was approved by the ethics committee of the Helwan University, Faculty of physical education, Giza, Egypt and gave their written informed consent. None of these subjects had any noteworthy medical history, especially with respect to neurological problems. The participants were familiarized in advance with the laboratory procedures and were asked on the test days to arrive well hydrated and at least $2 \mathrm{~h}$ after a light meal and not to have performed any strenuous exercise during the 24 $\mathrm{h}$ period immediately prior to testing. All participants were admitted to a skills evaluation test at the morning before the competition and after the competition.

\section{Blood analyses:}

Blood samples were collected before and immediately after exercise set in the two groups, in heparinized tubes, centrifuged at $1000-1500 \mathrm{~g}$ for $10 \mathrm{~min}$., plasma were separated and frozen at $-20{ }^{\circ} \mathrm{C}$ until analysis. S-100 $\beta$ protein levels were measured using an ELISA assay kit (Calbiochem, San Diego, CA).

\section{Statistical analysis:}

A Computer program (SPSS version 20) was used to analyze obtained results. Student's Mean, standard deviation of players and $\mathrm{T}$ Test were used to examine the difference between baseline and after exercise measurements in each group. Probability was assigned significant at $\leq 0.05$.

\section{Results}

There were elevated plasma $S-100 \beta$ levels after exercise compared to that obtained before exercise lead to significant increase in both the two groups $(\mathrm{P}<0.001)$ (Table 1).

Table (1)

Results of S-100ß protein in athletes at rest compared to that after events

\begin{tabular}{|c|c|c|c|c|c|}
\hline & Before & After & $\mathrm{t}$ & $\mathrm{p}$ & significance \\
\hline High jump & $53.4 \pm 14.66$ & $103.3 \pm 13.53$ & 8.753 & $<0.001$ & $\mathrm{~S}$. \\
\hline Pole vault & $54.3 \pm 10.99$ & $120.2 \pm 15.12$ & -12.175 & $<0.001$ & $\mathrm{~S}$. \\
\hline \multicolumn{7}{|c|}{ Results are expressed as [Mean $\pm \mathrm{SD}(\mathrm{pg} / \mathrm{ml})]$} \\
\hline
\end{tabular}

S-100 $\beta$ protein levels were maintained all over assayed samples with no difference in rest, indicating no significant $\mathrm{p}$ value which equals 0.886 . Difference between pole vault group was highly significant compared to that obtained in high jump group $(\mathrm{p}<0.02)$ (Table 2$)$. 
Table(2)

Results of S-100ß protein of pole vault athletes compared to that of high jump

\begin{tabular}{|c|c|c|c|c|c|}
\hline & High jump & Pole vault & $\mathrm{t}$ & $\mathrm{p}$ & significance \\
\hline Before & $53.4 \pm 14.66$ & $54.3 \pm 10.99$ & -.147 & .886 & NS \\
\hline After & $103.3 \pm 13.53$ & $120.2 \pm 15.12$ & -2.897 & $<0.02$ & $\mathrm{~S}$ \\
\hline \multicolumn{7}{|c|}{ Results are expressed as [Mean $\pm \mathrm{SD}(\mathrm{pg} / \mathrm{ml})]$} \\
\hline
\end{tabular}

There were significant decrease in skills performance after exercise compared to that obtained before exercise in both the two groups ( $\mathrm{P}<0.001)$ (Table 3).

Table(3)

Skills evaluation for athletes before events compared to after events

\begin{tabular}{|c|c|c|c|c|c|}
\hline & Before & After & $\mathrm{t}$ & $\mathrm{p}$ & Significance \\
\hline High jump & $3.5 \pm 0.26$ & $4.72 \pm 0.25$ & -49.000 & $<0.001$ & S. \\
\hline Pole vault & $3.3 \pm 0.28$ & $4.67 \pm 0.29$ & -20.466 & $<0.001$ & S. \\
\hline
\end{tabular}

Skills recorded degrees were maintained within all athletes with no difference in rest, indicating no significant $\mathrm{p}$ value which equals 0.619. Difference between pole vault group was not significant compared to that obtained in high jump group ( $p$ $=0.104)($ Table 4$)$.

Table(4)

Skills evaluation of pole vault athletes compared to that of high jump

\begin{tabular}{|c|c|c|c|c|c|}
\hline & High jump & Pole vault & $\mathrm{t}$ & $\mathrm{p}$ & significance \\
\hline Before & $3.5 \pm 0.26$ & $3.3 \pm 0.28$ & .514 & .619 & NS \\
\hline After & $4.72 \pm 0.25$ & $4.67 \pm 0.29$ & 1.809 & .104 & NS \\
\hline
\end{tabular}

\section{Discussion}

Aim of this study was to investigate effects of two famous field and track events on the brain integrity. S-100 $\beta$ protein is known to be a marker of brain damage. Several reports suggested that the over-expression of S-100 $\beta$ protein might exacerbate neurodegenerative diseases (Griffin et al. 1989, Sheng 1997, Himeda et al. 2006). Importantly, it is generally believed that $\mathrm{S}-100 \beta$ does not cross the blood brain barrier (BBB) in normal physiological conditions. This study found a significant differences between results of $S-100 \beta$ proteins and skills evaluation due to the competition events $(\mathrm{P}<0.001)$ for all athletes.

The development of hyperthermia, increased serotonergic activity, elevated circulating ammonia and epinephrine levels and increased production of proinflammatory cytokines may contribute to this response of lowered results of skills evaluation obtained after events.

Concentrations of this protein were assessed before and after amateur boxing competitions and sparring bouts and in several other games, including before and after a $25 \mathrm{~km}$ race, jogging $(10 \mathrm{~km})$, short-term running, and heading in football. S-100 $\beta$ protein levels increased after boxing and running, but not after ergometer cycling or soft heading of footballs. Increases in S-100 $\beta$ protein concentrations after competitive boxing and a $25 \mathrm{~km}$ race were significantly higher than with other activities. There was no significant difference between the effects of sparring and running. The number and severity of strikes to the head correlated significantly with increased $\mathrm{S}-100 \beta$ protein levels (Otto et al. 2000).

Increased S-100 $\beta$ levels after a 7600 meter swimming race as compared to baseline values suggests an acute influence of physical exercise on serum S-100 $\beta$ levels that is not related to CNS injury. Moreover, physical activity on a running wheel induces increased blood vessel density in brain (Abbott 2005 \& Schulte et al., 2011) and daily forced exercise on a treadmill also induces cortical and striatal angiogenesis ( Ballabh et al. 2004,). Such angiogenesis may be necessary to satisfy the brain's increased demand for oxygen and glucose ( $\mathrm{Li}$ et al. 2005). This is may an explanation of diminished concentration of skills after the events resulted in this study.

These findings have two important implications: 1) altered BBB integrity during exercise may disturb normal brain function and contribute to the development of central fatigue; and 2) serum S-100 $\beta$ is now employed as an index of brain trauma in individuals who suffer brain injuries during sports. Changes in the permeability of the BBB to this protein may give misleading results in exercising individuals, particularly under conditions that lead to significant heat stress (Watson et al. 2005).

The BBB maintains brain homeostasis by restricting the movement of molecules based on size, charge, hydrogen potential, and lipid solubility. Whereas many compounds penetrate the BBB by passive diffusion, many other agents undergo active influx or efflux using transport proteins. It has been recently postulated these processes are all affected by exercise-induced BBB damage (Nierwińskalet al., 2008). 
Recent studies have provided evidence that hyperthermia profoundly influences brain function during exercise, resulting in altered brain activity, reduced voluntary activation of muscle during sustained contractions and increased perception of effort (Schulte et al., 2011). Fatigue may be mediated through mechanisms residing within the central nervous system (CNS), but at present the neurobiological mechanisms that may be involved are not apparent.

There is some evidence that prolonged exercise may lead to increased BBB permeability. These changes were found to be relatively acute, with normal BBB function restored $2 \mathrm{~h}$ after exercise. Additionally, there is some evidence that exercise leads to an increase in serum S-100 $\beta$ concentrations (Mussack et al., 2003), but the possibility that this resulted from a change in BBB integrity has not been considered.

As an explanation of significant high differences between Pole vault athletes compared to that obtained in high jump is the technique of the games since pole vault players need to drop vertically on the coach after jumping while high jumper usually pass the horizontal bar in a somewhat horizontal movement which lead to somewhat low head striking on the coach.

There are contradictory opinions concerning the intensity of physical activity which can lead to a significant increase of S-100 $\beta$ in serum. Hasselblatt et al. (2004) suggest a muscular origin due to myofibrillar injury after marathon running. Some researchers have suggested that the influence of exercise on the CNS could be associated with either changes in serotonin levels and its receptors which increases intracellular content and release of astrocytic S-100 $\beta$ (Dietrich et al., 2003) and/or increased BBB permeability (Watson et al., 2006).

\section{Conclusions}

S-100 $\beta$ was released into the blood of the players as a consequence of game-related activities and events. It is higher in levels in pole vault athletes related to high jump. S-100 $\beta$ analysis as a biochemical marker for brain damage seems to have the potential to become a valuable additional tool for assessment of the degree of brain tissue damage in sport-related head trauma and probably for decision making about inhibiting/returning to play. According to the 3rd International Conference on Concussion in Sport held in Zurich 2008, concerning consensus statement on concussion in sport, athletes must submitted to a skill evaluation and brain concentration after every competition to evaluate and exclude post event minor concussions.

\section{Refernces}

1. Abbott N.J. (2005) Dynamics of the CNS barriers: evolution, differentiation, and modulation. Cell. Mol. Neurobiol. 25, 5-23.

2. Ballabh P., Braun A., Nedergaard M. (2004) The blood-brain barrier: an overview. Structure, regulation, and clinical implications.

Neurobiol. Dis. 16, 1-13.
3. Dietrich MO, Tort AB, Schaf DV, Farina M, Goncalves CA, Souza DO, and Portela LV. Increase in serum S100B protein level after a swimming race.

Can J Appl Physiol 28: 710-716, 2003.

4. Griffin W.S., Stamley L.C., Ling C., White L., Macleod V., Perrot L.J., White J.C., Araoz C. (1989) Brain interleukin 1 and S-100 immunoreactivity are elevated in down syndrome and Alzheimer disease. Proc Natl.,

Acad. Sci. USA 86, 7611-7615.

5. Hasselblatt M, Mooren FC, von Ahsen N, Keyvani K, Fromme A, Schwarze-Eicker K, Senner V, and Paulus W. Serum S100_increases in marathon runners reflect extracranial release rather than glial damage.

Neurology 62: 1634-1636, 2004.

6. Himeda T., Watanabe Y., Tounai H., Hayakawa N., Kato H., Araki T. (2006): Time dependent alterations of co-localisation of S100 $\beta$ and GFAP in the MPTP-treted mice.

J. Neural Transm. 113, 1887-1894.

7. Isobe T., Takahashi K., Okuyama T. (1984) S-100a a (alpha alpha) protein is present in neurons of the central nervous system.

J Neurochem, , 43, 1494-1496.

8. Kapural M., Krizanac-Bengez L., Barnett G., Perl J., Masaryk T., Apollo D., Rasmussen P., Mayberg M.R., Janigro D. (2002) Serum S-100 $\beta$ as a possible marker of blood-brain barrier disruption.

Brain Res. 940, 102-104.

9. Kiełbiński M., Sołtys Z. (2008) S100 protein, astrocytes and memory.

Post. Biol. Kom, 35, 3-13

10. Li J., Ding Y-H., Rafols JA., Lai Q., McAllister II JP., Ding Y. (2005) Increased astrocyte proliferation in rats after running exercise. Neurosci.

Lett. 386. 160-164.

11. Maramatsu Y., Kurosaki R., Watanabe H., Michimata M., Matsubara M., Imai Y., Araki T. (2003) Expression of S100beta protein is related to neuronal damage in MPTP-treated mice.

Glia 42, 307-313.

12. McCrory, P., Meeuwisse, WH., Aubry, M., Cantu, B., Dvořák, J., Echemendia, JE., Engebretsen, L., Johnston, K., Kutcher, JS., Raftery, M., Sills, A., Benson, BW., Davis, GA., Ellenbogen, RG., Guskiewicz, K., Herring, SA., Iverson, GL., Jordan, BD., Kissick, J., McCrea, M., McIntosh, AS., Maddocks, D., Makdissi, M., Purcell, L., Putukian, M., Schneider, K. and Tator, CH. (2013): Consensus statement on concussion in sport: the 4th International Conference on Concussion in Sport held in Zurich, November 2008

Br J Sports Med 2009;47:250-258 
13. Nielsen B, Hyldig T, Bidstrup F, Gonzalez-Alonso J, and Christoffersen GR. (2001): Brain activity and fatigue during prolonged exercise in the heat.

Pflügers Arch 442: 41-48, 2001.

14. Nierwińska1, K., Malecka, E., Chalimoniuk, M., Żebrowska1,A. and Langfort, J. (2008): Blood-Brain Barrier and Exercise - a Short Review

Journal of Human Kinetics volume 19, 2008, 83-92

15. Nybo L and Nielsen B. (2001-A): Hyperthermia and central fatigue during prolonged exercise in humans. J Appl Physiol 91: 1055-1060, 2001.

16. Nybo L and Nielsen B. (2001-B): Perceived exertion is associated with an altered brain activity during exercise with progressive hyperthermia.

J Appl Physiol 91: 2017-2023, 2001.

17. Otto M., Holthusen S., Bahn E., Söhnchen N., Wiltfang J., Geese R., Fischer A., Reimers C.D. (2000) Boxing and running lead to a rise in serum levels of S- $100 \beta$ protein.

Int. J. Sports Med. 21, 551-555

18. Schulte, S., Schiffer, T., Sperlich, B., Kleinöder, H. and Holmberg, HC. (2011): Serum Concentrations of S100B are not Affected by Cycling to Exhaustion With or Without Vibration

Journal of Human Kinetics volume 30/2011, 59 - 63

19. Sendrowski K., Sobaniec W., Sobaniec-Łotowska M.E., Lewczuk P. (2004) S-100 protein as marker of the blood-brain barrier disruption in children with internal hydrocephalus and epilepsy - a preliminary study. Roczniki Akademii Medycznej w Biatymstoku, 49.

20. Sheng J.G., Mark RE., Griffin WS. (1997) Glialneuronal interactions in Alzheimer disease: progressive association of IL-1alpha+microglia and S100beta+astrocytes with neurofibrillary tangle stage.

J. Neuropathol. Exp. Neurol. 56, 285-290.

21. Watson P., Black K.E., Clark S.C., Maughan R.J. 2006. Exercise in the heat: effect of fluid ingestion on bloodbrain barrier permeability. Med. Sci. Sports Exerc. 38, 2118-2124.

22. Watson, P., Shirreffs, SM and Maughan, RJ. (2005): Blood-brain barrier integrity may be threatened by exercise in a warm environment.

Am J Physiol Regul Integr Comp Physiol 288: R1689 R1694, 2005. 
